\title{
Just a Notion of Aid: How (Not) to Create a Fiscal State Aid Doctrine
}

\author{
Raymond Luja*
}

\begin{abstract}
The European Commission's review of over 1,000 tax rulings across the European Union (EU) bas drawn a lot of attention in recent years, with the EUR 13 billion Apple decision as its pinnacle for now (moneywise). ${ }^{1}$ It led to beated discussions between EU and US politicians and officials, as the Commission ordered certain large US companies (as well as others) to pay taxes it considered due with regard to fiscal years that were considered settled before.
\end{abstract}

\section{The value of state aid PRecedents}

In May 2016 the European Commission published a notice containing its view on how to explain what is and what is not state aid (the 2016 Notice) ${ }^{2}$ In the area of direct taxation, it replaces its rather rudimentary predecessor of 1998. Professor Wattel will discuss the 2016 Notice in detail in this issue of Intertax.

A Commission document interpreting a particular area of law can indeed be a helpful tool to get a first grasp on a particular legal issue. It might even raise, under strict conditions, legitimate expectations that may stand in the way of recovery of unlawful state aid in the future. The latter may be conceived as a 'good' thing for taxpayers involved as we need some certainty in these turbulent times. However, competitors who rely on state aid rules to protect their interest may lose out in the long run if the Commission's visions differ from that of the Court of Justice of the European Union (CJEU).

The 2016 Notice is a mixture of broadly shared interpretations of CJEU case law, CJEU case law with a particular interpretation added, a reflection of consistent Commission decision making practice and even new thoughts and lines of argument included in single decisions that were still open to legal challenge at the time the Notice was published (like Starbucks, Fiat and the Belgian Excess Profit scheme). ${ }^{3}$ So we should be careful not to assume that everything in the Notice reflects consistent and established practice which has the CJEU's blessings, although, admittedly, most of it does. The 2016 Notice is a good primer for lawyers that want to get acquainted with what state aid is all about, but anyone actually wanting to use the Notice needs to go back to actual decisions and judgements to get a grasp of the context in which certain rules were first applied.

In a rather recent state aid case, the EU's General Court recalled the following:

[L'Etat Membre] invoque la pratique décisionnelle antérieure de la Commission [ ... ]. En effet, il importe de rappeler, sans qu'il soit nécessaire d'examiner si la pratique invoquée est établie, qu'elle ne saurait affecter la validité de la décision attaquée, laquelle ne peut s'apprécier qu'au regard des règles objectives du traité [ ... ]. Dès lors, elle ne saurait dépendre d'une appréciation subjective de la Commission et doit être déterminée indépendamment de toute pratique antérieure de cette institution. ${ }^{4}$

\section{Notes}

Professor of Comparative Tax Law and Head of the Department of Tax Law at Maastricht University, the Netherlands; fiscal state aid counsel to Loyens \& Loeff N.V., Amsterdam. The views expressed here are those of the author and they do not necessarily reflect the views of Loyens \& Loeff N.V. Email: Raymond.Luja@maastrichtuniversity.nl.

EUR 13 billion is a Commission estimate of the maximum amount due, excluding interest; Ireland will have to make the final calculation. See European Commission Press Release IP/16/2923 of 30 Aug. 2016.

2 Commission Notice on the Notion of State Aid as Referred to in Article 107(1) of the Treaty on the Functioning of the European Union, Official Journal of the EU (OJ) C 262/1 of 19 July 2016.

Commission Decision of 21 Oct. 2015, SA.38374, Starbucks, not yet published; Commission Decision of 21 Oct. 2015, SA.38375, Fiat, not yet published; Commission Decision of 11 Jan. 2016, SA.37667, Excess profit exemption, OJ L 260/61 of 27 Sept. 2016. All cases are under appeal.

4 T-143/12 of 14 July 2016, Germany v. Commission (Deutsche Post), ECLI:EU:T:2016:406, para. 126. Also see C-138/09 of 20 May 2010, Todaro Nunziatina v. Commission, EU: C:2010:291, para. 21, T-303/10 of 27 Sept. 2012, Wam Industriale v. Commission, ECLI:EU:T:2012:505, para. 82 and T-500/12 of 5 Feb. 2015, Ryanair v. Commission, ECLI EU:T:2015:73, para. 39. 
In essence, the General Court limits the relevance of the Commission's decision making practice in order to ensure that only the objective language of the Treaty will be decisive. It is a basic legal principle: even a consistent series of administrative decisions cannot change the statutory definition of state aid. Even if the outcome of decisions is paraphrased in an official Commission Notice, its relevance should not change. It is for the CJEU to give a definite interpretation of the Treaty on the Functioning of the European Union (TFEU) in the end. ${ }^{5}$

Only a few weeks after the publication of the 2016 Notice, a Commission Staff Working Paper has been issued dealing with tax rulings in response to a call for further clarification. ${ }^{6}$ If the working paper would just do that, it would be a nice read. But it goes far beyond that by identifying a number of characteristics of rulings that may serve as yellow flags. These also include positions not reflected in the 2016 Notice, such as the flagging of unilateral adjustments and of the use of deductions of virtual payments to downwardly adjust taxable profit (even if to an at arm's length level?). A Staff working paper is not meant to be binding on the Commission, unlike the 2016 Notice, so what should we think of such positions that did not make it into the official Notice just a few weeks before?

\section{2 (How to bRING AN END to) taX BUSINESS AS USUAL?}

As Competition Commissioner Vestager reflected, 'state aid control cannot change tax legislation. If tax legislation is to be changed, it is by the front door' ${ }^{7}$ This statement may serve as a reminder that, in the Commission's view, it is applying national tax legislation as it should have been applied by Member States in the past. Whether this is actually so will be fiercely debated in court in the years to come. The ongoing series of tax ruling decisions may set new standards and the first few would deserve a Grand Chamber at the CJEU. Not because of the huge sums involved in some of these cases, but because the CJEU may have to deal with the viability of national principles of taxation under state aid law.

For instance, are unconditional tax exemptions allowed if there is not even a chance of actual foreign taxation to justify them? Are Member States required to have an at arm's length principle? If so, may they adopt a default rule attributing all profits to a head office except for the part that is clearly attributable to a permanent establishment $(\mathrm{PE})$ ? Or is such a rule a no go, even when tax authorities may lack the necessary time and resources to dig into each and every case presented to them? And how much substance does a head office or PE require to be recognized? Or is substance something that is exclusively for the Member States to determine, even if lenient rules might benefit multinationals? How much time should tax authorities invest into following up on facts assumed in a tax ruling, before any remaining discrepancy is out of reach of state aid scrutiny? We need answers to questions like these, but it will be hard to place the CJEU in a position to actually answer them due to procedural constraints.

I have called upon Member States in the past to intervene in fiscal state aid cases that will have a standardsetting impact. If ever, this is the time to do so. I am not calling upon them to defend any of the individual rulings as such but to contribute to setting the limits of state aid scrutiny. If the CJEU decides to clarify the rules of the game, then Member States should make themselves heard before it does. This is easier said than done; from a public relations perspective a Member State's intervention at the side of another Member State may (too) easily be construed as defending harmful tax practices instead of being seen as a much needed contribution to the development of European law and an effort to protect its own fiscal sovereignty.

A Court with a mindset to limit harmful tax competition may well go along with the Commission's line of thought that group companies and stand-alone companies should be treated alike, as that maxim might make sense at first to many. Explaining why group companies are different from stand-alone companies is sometimes hard to do, despite the fact that the mere existence of mergers \& acquisitions already serves as a strong indicator that the economics of a company's operations may change because of being part of a group, be it economies of scale, synergy effects at large or otherwise. Think of joint purchases, shared services, long-term relationships, collective (intragroup) debt financing etc. Acting within a market economy is not the same thing as acting as a fully independent party; this is not just a matter of semantics. National anti-avoidance rules are needed to deal with differences like these.

The EU's state aid framework is not meant to be a substitute for proper anti-tax avoidance legislation, although it might affect such legislation, if enacted, when it comes with built-in escapes for certain sectors of industry that are hard to justify. The decision whether

\section{Notes}

To the extent the Commission's position is not in line with the Treaty as interpreted by the CJEU, that position cannot be relied upon in order to maintain a particular tax incentive for the future. Compare T-60/06 RENV II and T-62/06 RENV II, Eurallumina, ECLI:EU:T:2016:233, para. 127 and C-409/00 Spain v. Commission, ECLI:EU: C:2003:92, paras 69 and 95. To the extent a Notice addresses the Commission's way of analysing the economic effects of a case seems to enjoy a bit more leeway.

DG Competition working paper on State aid and tax rulings of 3 June 2016, http://ec.europa.eu/competition/state_aid/legislation/working_paper_tax_rulings.pdf. Statement made in the European Parliament's Apple decision debate on 14 Sept. 2016.

Apart from the various tax ruling cases, another potential standard-setting case that may deserve the intervention of (other) Member States in the near future is the upcoming decision on the Gibraltar 2010 corporate tax regime. It deals with taxation of active versus passive income, the need for effective ex-post controls and the use of schedular tax systems. (See the opening decision in case SA.34914, OJ C 348/184 of 28 Nov. 2013, and the extension thereof, OJ C $365 / 555$ of 7 Oct. 2016). 
or not to introduce effective anti-avoidance rules still is the prerogative of the individual EU Member State to the extent no harmonization at EU level is reached (as with the recent Anti-Tax Avoidance Directive, for instance). ${ }^{9}$

A nice example of how politics may mingle with state aid rules can be found in the press release concerning Apple. ${ }^{10}$ The Commission allowed Ireland to actually lower the amount to be recovered if other Member States would decide to tax more of the overall profit, once they realize what was (not) going on in Ireland (if they hadn't before). This may seem to make sense - to those who see this as a way to avoid double taxation while allowing each country to claim its fair share - as much as it makes no sense at all - to those who would argue that Member States should calculate taxable profit using their own methods even if other countries claim part of it. But then again, who would have a legal interest in challenge this little but crucial detail at the CJEU?

What worries me most is the uncertainty all of this created. The Commission does not need a new state aid doctrine to win some of its current tax cases, but its attempt to introduce best practices into the tax systems of Member States may result in the Commission having to redraft a few of the recovery decisions it took before they might actually stick. In the meantime some Member States may feel pressured by companies to start notifying tax rulings to the Commission, just to get the legal certainty they need. This is not a sustainable way to end uncertainty in the market and it might divert Commission resources away from doing the investigations it needs to do. ${ }^{11}$

\section{The UPSIDE OF HAVING STATE AID RULES}

State aid rules are often perceived as uneasy limitations to tax planning practices. Auditors and tax lawyers wonder whether something is state aid or not, and, if so, is there a threat of retroactive taxation (recovery). They have little time to consider that the idea behind state aid rules is to save an internal market from certain kinds of government intervention and - in recent years - to improve the quality and effectiveness of public spending at the same time. Lately the Commission has done a tremendous job by modernizing state aid rules to improve the awareness of the (in)effectiveness of certain subsidies and to decrease oversubsidization of certain economic activities. Businesses and politicians tend to focus on the downside of state aid rules, but these rules do deserve a little more credit as a last line of defence against special interest groups and lobbyists.

State aid rules are here to stay, at least for those countries that are Members of the EU. For a country with plans to exit the EU it is unlikely that any lasting agreement with the EU on free trade would be one without some similar provisions. In the absence of such safeguards, the EU might face a potential tax competitor at its borders unrestrained by state aid limitations. For the country that exits, it might be losing the upside of having a state aid regime when it comes to reigning in tax expenditure. Its politicians can no longer point the finger to an EU supervisor in Brussels as an excuse not to introduce certain benefits for lingering companies or ailing sectors of industry. But then, this would be part of the joy of regained national fiscal sovereignty.

\section{Notes}

9 Council Directive (EU) 2016/1164 of 12 July 2016 laying down rules against tax avoidance practices that directly affect the functioning of the internal market, OJ L 193/1 of 19 July 2016

10 Supra n. 1. The text of the final decision was not available at the time this editorial was finished (21 Sept. 2016) and that decision may show a more nuanced position.

11 The Commission does (still) allow for the notification of measures that Member States consider not to be state aid in order to acquire legal certainty, even though the procedure set forth in Council regulation 2015/1589 (OJ L 248/9 of 24 Sept. 2015) does not require it to do so. See Annex I to Commission regulation 794/2004 (OJ L 140/1 of 30 Apr. 2004, as amended), question $1(\mathrm{~d})$. 